\title{
MITOLOGI DALAM VIDEO GAME: PESAN-PESAN POLITIK DALAM VIDEO GAMES AMERIKA SERIKAT
}

\author{
Fajriannoor Fanani \\ (carbudit@yahoo.com) \\ Pengamat Kebijakan Media
}

\begin{abstract}
Video Game, especially in Indonesia, has been long seeing as kid toy with minimum or no psychological impact to the player. This view is a serious mistake since video game able to transmit violence message to political message into their audience or player. Political message especially is very omnipresent in such game as Red Alert, Generals and others FPS or RTS games. The message on these games is higly political and contains political views the developer has. This writing tries to read the political messages on games like Red Alert and Counter Strike to find myth the developer create or believe and search out why these myths is present. Barthes analysis on semiotics were used to read not only the denotative meaning of the message, but also find the connotative message and finaly find the myths wrapped around the games.
\end{abstract}

Keywords: mythologies, video game, manifest destiny.

Dunia game selama ini telah banyak luput dari kajian dalam ilmu komunikasi. Para akademisi, terutama di Indonesia, agaknya menyepelekan pesan yang dapat dimuat oleh sebuah video game. Akademisi mungkin juga menganggap bahwa pesan dalam video game adalah fenomena yang jauh karena toh produsenprodusen video game besar berada diluar Indonesia, di Jepang, Amerika Serikat, dan Eropa. Penulis sendiri, sebagai salah satu pecinta video game, melihatnya dalam cara yang berbeda. Tulisan ini akan mencoba memperlihatkan bagaimana video game seringkali memiliki pesan yang kompleks, mitologis, dan ideologis.

\section{PENDAHULUAN}

Kebanyakan akademisi komunikasi, terutama di Indonesia, lebih menfokuskan kajian mereka pada media yang lebih umum seperti Televisi, Radio, Koran, Majalah, Lagu, Film, Poster, Iklan, dan lain-lain. Video Game mungkin dianggap kurang memiliki unsur komunikasi dimana pesan yang disampaikan tidaklah terlalu jelas. Jika pun ada mungkin pesan tersebut dianggap kurang penting karena hanya ditujukan sebagai hiburan ringan. Padahal pesan video game selama ini telah banyak diteliti secara serius oleh akademisi luar. Penelitian yang ada selama ini lebih menyoroti dampak kekerasan dalam video game terhadap perilaku kekerasan anak. Pakar militer psikologi tempur dari Amerika Serikat, Col. David Grossman, misalnya mengatakan bahwa video games adalah simulator pembunuhan. Bahkan dalam kasus-kasus penembakan di Amerika Serikat ditemukan bahwa beberapa pelaku tidak pernah memegang senjata sebelumnya (Anonymus. (2010). Violence: Shatter the Silence. Listen, Nov; 64. 3: 7). Hasil bernada positif sementara itu juga muncul dalam penelitian Lee dan Probert yang meneliti dampak dari game Civilization III terhadap anak kelas sebelas. Mereka berkesimpulan bahwa Civilization III memiliki gameplay yang kompleks dan membutuhkan cara berfikir yang kreatif. Mereka bahkan mengusulkan bahwa para guru dapat menggunakan game tersebut dalam pengajaran kelas- 
kelas sejarah (Lee, John K. dan Jeffrey Probert. (2010). Civilization III and Whole-Class Play in High School Social Studies. The Journal of Social Studies Research, Volume 34, Issue 1:1).

Gencarnya penelitian mengenai video games di luar negeri menunjukkan bahwa video games adalah bagian dari dunia komunikasi yang telah memiliki muatan pesan yang kompleks dan berdampak luas. Video games abad 21 tidak lagi seperti video games pada masa lalu seperti pong, pac man, atau star invaders yang sederhana, ber-gameplay linear ${ }^{1}$, dan tidak memiliki banyak muatan pesan. Video games saat ini telah memiliki banyak genre yang masing-masing memiliki gameplay dengan muatan yang khas. Ada genre game First Person Shooter (FPS) seperti Counter Strike, dan Halo yang penuh dengan adegan kekerasan tembak menembak, ada juga game adventure seperti Grand Theft Auto (GTA) yang tidak hanya bermuatan kekerasan tembak menembak namun juga ada unsur pencurian, bahasa yang kasar, dan seksual. Ada juga game-game yang lebih netral seperti game sport dan racing seperti Pro Evolution Soccer dan Need for Speed. Terakhir, dan yang akan dibahas dalam tulisan ini, adalah game RTS seperti Red Alert dan Generals yang tidak hanya memiliki unsur strategi peperangan, namun juga kental akan muatan-muatan politik dan ideologis.

Sejak lahir beberapa dekade lalu pesan dalam video game telah banyak berubah. Video game yang awalnya hanya ditujukan untuk menghibur kini memiliki banyak pesan yang kompleks, termasuk didalamnya adalah pesan-pesan politik yang kadang terlihat sangat eksplisit dan kadang implicit. Seri game Wolfenstein misalnya secara eksplisit menempatkan

1 Gameplay linear adalah gameplay yang artinya setiap orang yang memainkan game ini akan mengikuti alur cerita yang telah ditentukan oleh pembuat game tersebut
Jerman Nazi sebagai pihak yang sangat jahat dan Amerika Serikat sebagai jagoan yang menyelamatkan dunia dari plot jahat Nazi. Secara implisit pola Amerika versus Nazi ini juga dapat ditemui dalam seri legendaris Medal of Honor yang lebih menekankan pada realitas pertempuran dalam format FPS.

Pesan politik yang sama dengan musuh yang berbeda juga dapat ditemui dalam seri legendaris lainnya, Red Alert, dalam seri ini Amerika digambarkan harus melawan aggressor komunis Uni Soviet yang siap menguasai dunia. Tema agresivitas komunis dan Uni Soviet ini juga dapat ditemui dalam game-game seperti World in Conflict, Operation Flashpoint: Cold War Crisis, dan lain-lain yang selalu mengusung Amerika Serikat sebagai jagoannya.

Selain nazi dan komunis para developer game ini juga sering menjadikan ikon-ikon Islam atau orangorang timur tengah sebagai the bad guy. Game multiplayer legendaris, Counter Strike, dengan jelas memperlihatkan hal ini. Game lain yang sangat eksplisit adalah Command \& conquer: Generals yang jelas menggambarkan suatu faksi timur tengah dengan sangat negatif dan kejam.

Belum puas menjadikan Nazi, komunis, dan orang-orang timur tengah sebagai musuh, para developer game menambah satu musuh lagi bagi Amerika, yaitu China. Masih di game Command \& conquer: Generals, China juga digambarkan sebagai faksi yang negatif. Di game lain, seperti Operation Flashpoint: Dragon Rising China juga digambarkan agresif dan musti dihentikan oleh sang jagoan, Amerika Serikat.

Berdasarkan contoh-contoh game tersebut terlihat jelas bahwa para developer game, yang sebagian besar berbasis di Amerika Serikat, memiliki pandangan pro Amerika yang uniknya memusuhi banyak budaya lain. Pandangan 
ini tampaknya tertanam dalam kepala mereka dan tertuang sebagai mitologi dalam setiap produk game mereka.

Konsep mitologi dalam tulisan ini diambil dari konsep mitologi Barthes dalam rumusan mengenai semiotika-nya. Akan tetapi sebelum memahami analisis semiotika Barthes terlebih dahulu kita harus memahami konsep semiotika Ferdinand D. Saussure. Saussure meletakkan tanda dalam konteks komunikasi manusia dengan melakukan pemilahan antara apa yang disebut signifier (penanda) dan signified (petanda). Signifier adalah bunyi yang bermakna atau coretan yang bermakna (aspek material), yakni apa yang dikatakan dan apa yang ditulis atau dibaca. Signified adalah gambaran mental, yakni pikiran atau konsep aspek mental dari bahasa. (Sobur, 2004: 125). Menurut Saussure tanda (Sign) bersifat arbitrary dimana kombinasi antara Signifier dan signified adalah entitas yang manasuka. Tidak ada hubungan yang natural antara signifier dan signified. Tidak ada alasan intrinsik mengenai mengapa sebuah benda diberi nama sesuai dengan namanya tersebut. (Culler, 1990: 19).

Roland Barthes mengembangkan konsep signifier dan signified Saussure tersebut secara lebih lanjut. Ia menciptakan dua tingkatan pentandaan (staggered systems), yang memungkinkan untuk dihasilkannya makna yang juga bertingkat-tingkat, yaitu tingkat denotasi (denotation) dan konotasi (connotation). Denotasi adalah level makna deskriptif dan literal yang secara virtual dimiliki semua anggota suatu kebudayaan. Pada level kedua, konotasi, makna dibangun oleh penanda yang mengaitkan dengan aspek budaya yang lebih luas: keyakinan, sikap, kerangka kerja, dan ideology suatu bangunan sosial. Makna menjadi persoalan asosiasi tanda dengan kode makna budaya lain. Ketika konotasi dinaturalisasikan sebagai sesuatu yang hegemonic, yaitu ketika diterima secara 'normal' dan 'alami', ia bertindak sebagai peta makna konseptual dimana seseorang memahami dunianya. Itu semua adalah mitos. (Barker, 2005: 72).

Gambar 1

Pemaknaan Mitos dari Barthes

\begin{tabular}{|c|c|c|c|}
\hline \multirow{3}{*}{$\begin{array}{l}\text { Bahasa } \\
\text { MITOS }\end{array}$} & $\begin{array}{r}1 \text { Penanda } \\
\text { (Signifier) }\end{array}$ & $\begin{array}{l}2 \text { Petanda } \\
\text { (Signified) }\end{array}$ & \\
\hline & \multicolumn{2}{|c|}{3 Tanda } & \\
\hline & \multicolumn{2}{|c|}{ PENANDA I (Denotation) } & PETANDA II (Connotation) \\
\hline
\end{tabular}

Diambil dari (Barker, 2005: 73).

Tabel ini memperlihatkan bahwa Barthes tidak hanya melihat suatu produk budaya secara harfiah, ia berusaha untuk melihat produk tersebut hingga ke ideologi apa yang terkandung di dalamnya. Ia berusaha memahami mitologi apa yang sedang diterapkan oleh sang pembuat produk untuk mempengaruhi khalayaknya. Konsep mitologi inilah yang digunakan dalam penelitian ini. Produk-produk game ini tidak hanya dilihat sebagai produk hiburan semata, ada mitologi-mitologi yang sedang dicoba untuk ditanam, baik sadar maupun tidak, oleh para developer game terhadap konsumen atau khalayak produk tersebut.

\section{PEMBAHASAN}

Ada beberapa mitos yang sering muncul dalam berbagai video game perang bermuatan politis. Umumnya semuanya mempromosikan keunggulan Amerika Serikat dan barbarisme masyarakat non barat. Mitos-mitos ini tentu tidak hadir dalam ruang kosong, ada suatu kondisi sosial masyarakat Amerika Serikat yang ikut membentuk mentalitas "superpower" para developer game ini. Disinilah analisis Barthes menjadi 
berguna, karena Barthes tidak hanya mengartikan struktur teks yang telah ada, namun juga berusaha melakukan studi diakronik terhadap evolusi bahasa dalam setiap waktu (Culler, 1990: 35). Studi diakronik ini dilakukan melalui penelusuran kondisi sosial masyakarat dimana teks tersebut berkembang, dalam hal ini adalah masyarakat Amerika Serikat.

1. Masyarakat Amerika dan Warisan Manifest Destiny

Masyarakat Amerika bukanlah masyarakat paling pluralis dan liberal didunia. Walaupun media barat banyak menggambarkan Amerika sebagai negara dimana seluruh umat manusia bisa hidup dan bebas, pada kenyataannya sejarah Amerika sendiri banyak diwarnai dengan ketimpangan kultural, konflik ras, dan ketidakadilan sosial. Segera setelah orangorang Inggris mendirikan koloni di benua Amerika mereka harus berhadapan dengan pemilik asli tanah tersebut, orang-orang Indian. Konflik antara penduduk asli dan pendatang ini menghasilkan Perang Indian-Amerika yang berlangsung terputus-putus dari tahun 1622 hingga 1924. Hasil dari peperangan ini, berbagai kebijakan migrasi penduduk Indian, dan epidemi penyakit telah menyebabkan jumlah penduduk Indian menurun drastis dan kehilangan tanah-tanah mereka. Pada saat orang-orang Eropa datang terdapat 900.000 orang Indian di Amerika (Anonim. Destroying the Native American Culture.

Dalam http://www.loc.gov/teachers/classroomma terials/presentationsandactivities/presentat ions/immigration/alt/native_american.htm 1. Diakses pada tanggal 29 Februari 2012 pada pukul 16:24 WIB). Terakhir pada awal abad 20 jumlahnya telah menurun drastis hingga hanya sekitar 250.000 orang.

Setelah menghancurkan peradaban penduduk asli Indian, orang-orang Amerika Serikat kemudian melakukan ekspansi kebarat, menguasai setengah wilayah Mexico, dan bahkan menyerang Mexico City dalam perang MexicoAmerika. Amerika Serikat menang besar dan memperoleh wilayah-wilayah Texas, New Mexico, Nevada, Colorado, Utah, dan California yang sangat luas. Ekspansi Amerika ini kemudian dikomentari oleh Jenderal Ulysses Simpson Grant sebagai contoh yang sangat buruk dari ketidakadilan politik dimana yang kuat mengalahkan yang lemah. Ia mengatakan:

Generally, the officers of the army were indifferent whether the annexation was consummated or not; but not so all of them. For myself, I was bitterly opposed to the measure, and to this day regard the war, which resulted, as one of the most unjust ever waged by a stronger against a weaker nation. It was an instance of a republic following the bad example of European monarchies, in not considering justice in their desire to acquire additional territory. (U.S. Grant, Memoirs, On the annexation of Texas and the Mexican War. Diunduh dari

http://www.sewanee.edu/faculty/Willi s/Civil_War/documents/Grant.html.

Diakses pada tanggal 29 Februari 2012 pukul 16:37 WIB).

Setelah mengalahkan Mexico, Amerika pun harus bertempur satu sama lain dalam perang saudara dari tahun 1861 hingga 1865. Sebab dari pertempuran ini adalah permasalahan perbudakan, dimana presiden Amerika Serikat yang baru, Abraham Lincoln, mendapat pertentangan dari negara-negara bagian selatan kala ingin menghapus perbudakan di seluruh negeri. Perbudakan, ironisnya, saat itu masih jamak di Amerika Serikat terutama di negara-negara selatan, dan Amerika adalah salah satu negara barat terakhir yang menghapus perbudakan di negeri mereka. Sikap anti kulit hitam dan kulit berwarna lain ini kemudian tidak serta 
merta terhapus karena setelah perbudakan dihapuskan muncul organisasi-organisasi rasis kulit putih sayap kanan seperi $\mathrm{Ku}$ Klux Klan yang sangat anti kulit berwarna. Bahkan hingga saat ini organisasi-organisasi semacam itu masih ada di Amerika Serikat.

Bagaimana sebuah negara yang sangat mengadvokasi liberalisme memiliki catatan kelam mengenai ketidakadilan yang bahkan dilakukan negara terhadap masyarakat non kulit putih? Pertanyaan ini tentu sangat sulit dijawab, akan tetapi ada suatu pandangan yang berkembang pada masyarakat Amerika di masa lalu yang sedikitnya dapat menjawab hal tersebut, pandangan atau ide ini adalah Manifest Destiny. Istilah ini muncul dari tulisan John L. O'Sullivan pada tahun 1845 berjudul Annexation yang dimuat dalam United States Magazine and Democratic Review. Dalam tulisannya O'Sullivan berpandangan:

"manifest destiny of the United States to overspread the continent allotted by Providence for the free development of our yearly multiplying millions" (O'Sullivan, John L. (Summer 1845). Annexation. United States Magazine and Democratic Review. Dalam http://www.enotes.com/manifestdestiny-reference/manifest-destiny. Diakses pada tanggal 29 Februari 2012 pukul 16:57 WIB).

Pandangan ini menjustifikasi politik ekspansionis Amerika Serikat ke wilayahwilayah Indian dan terutama wilayahwilayah Mexico. Secara lebih lanjut pemahaman ini juga menjadi pandangan yang rasialis dimana yang mendapatkan "takdir/destiny" tak lain adalah warga negara kulit putih Amerika Serikat, dan Amerika sendiri ditakdirkan untuk menjadi milik warga negara kulit putih. Pandangan ini misalnya muncul dalam pidato John Calhoun, politikus Amerika yang berpengaruh pada saat perang Amerika-Mexico. Ia mengatakan:
"(W)e have never dreamt of incorporating into our Union any but the Caucasian race-the free white race. To incorporate Mexico, would be the very first instance of the kind, of incorporating an Indian race; for more than half of the Mexicans are Indians, and the other is composed chiefly of mixed tribes. I protest against such a union as that! Ours, sir, is the Government of a white race.... We are anxious to force free government on all; and I see that it has been urged ... that it is the mission of this country to spread civil and religious liberty over all the world, and especially over this continent. It is a great mistake" (Calhoun, John C. 1848. Conquest of Mexico. Dalam http://teachingamericanhistory.org/libr ary/index .asp?document=478. Diakses pada tanggal 29 Februari 2012 pada pukul 17:09 WIB).

Secara jelas Calhoun mengatakan bahwa Amerika Serikat adalah negara bagi orang-orang Caucasia kulit putih, oleh karenanya tidak ada tempat bagi warga negara latin, Indian, apalagi kulit hitam. Pandangan ini secara resmi mungkin memang tidak lagi digunakan oleh pemerintah Amerika Serikat, akan tetapi tampaknya pandangan ini masih memiliki dampak yang besar bagi warga negara Amerika Serikat kulit putih. Mereka masih merasa menjadi masyarakat nomer satu, manusia-manusia terbaik, dan tak mungkin melakukan kesalahan. Pandangan ini secara jelas muncul dalam doktrin-doktrin pemerintahan Bush seperti Pre-emptive Strike, demokratisasi rezimrezim asing, dan kebijakan menyerang negara-negara yang melindungi teroris. Doktrin-doktrin ini adalah kebijakan sepihak yang tidak menghormati kedaulatan dan kebebasan bangsa-bangsa lain. Apabila merasa terancam mereka boleh melakukan serangan terlebih dahulu, apabila ada tokoh yang dianggap 
teroris berlindung di suatu negara mereka boleh menyerang negara tersebut, dan yang paling sepihak adalah jika ada negara yang dinilai tidak demokratis maka mereka dapat memaksakan perubahan rezim dinegara tersebut.

Cara-cara pemerintahan Bush ditambah dengan kampanye membabibutanya dalam melawan teroris sedikit kurang adalah sisa-sisa peninggalan manifest destiny pada masyarakat mereka. Mereka merasa menjadi negara yang paling demokratis dan berhak memaksakan demokrasi tersebut ke negara-negara lain. Mereka juga berhak menyerang negara lain demi "kedamaian dunia", sebagai super-power mereka merasa menjadi polisi dunia yang berhak mengatur politik dunia, hal inilah yang akhirnya membawa mereka dalam peperangan yang berlarut-larut di Afghanistan dan Irak. Pandanganpandangan inilah yang kemudian menjadi mitologi masyarakat Amerika dan tertuang dalam produk-produk budaya mereka, termasuk video game. Berikut ini akan dijabarkan mitos-mitos yang dikembangan oleh para developer game Amerika.

\section{Mitos Defense War}

Hampir seluruh game-game yang telah disebutkan menempatkan Amerika Serikat atau barat sebagai pihak yang diserang. Pada seri game Red Alert pertama diceritakan bahwa untuk mencegah perang dunia ke-2, Albert Einstein menciptakan mesin waktu dan berhasil mencegah Adolf Hitler menjadi diktator Jerman, akan tetapi konsekuensinya adalah Uni Soviet menjadi superpower dan bergerak menguasai dunia. Disini sekutu, terutama Amerika, bertahan dari agresi Uni Soviet. Ada dua ending dari seri ini, pertama sekutu berhasil bertahan dan kedua Uni Soviet berhasil menguasai dunia. Pada seri kedua, Command \& Conquer: Red Alert 2, plot dimulai dari kekalahan Uni Soviet dan sekutu menaruh seorang pemimpin boneka untuk Uni Soviet, sayangnya pemimpin boneka ini menghimpun kekuatan diam-diam dan menyerang Amerika Serikat secara mendadak. Sama seperti seri awal ada dua ending untuk game ini, pertama adalah kemenangan Amerika dan kedua kemengangan Uni Soviet. Pada seri ketiga Command \& Conquer: Red Alert 3 pemimpin Uni Soviet yang berada dalam ambang kekalahan menggunakan mesin waktu untuk membunuh Albert Einstein, hal ini menyebabkan Uni Soviet kembali kuat di masa depan dan nyaris menguasai dunia, akan tetapi ternyata ada satu faksi lagi yang juga tumbuh menjadi kuat dan ingin menguasai dunia, yaitu Empire of the Rising Sun yang sangat menyerupai Jepang. Alhasil dalam seri ketiga ini Amerika Serikat harus melawan agresi dari dua faksi, yaitu Uni Soviet dan Jepang.

Pada game Command and Conquer yang lain, yaitu Generals, Amerika Serikat juga digambarkan melakukan serangan Pre-emptive Strike terhadap faksi GLA yang digambarkan sebagai faksi teroris timur tengah yang mengancam perdamaian dunia. Tema perlawanan terhadap agresi juga muncul dalam game World in Conflict. Pada game ini diceritakan bahwa untuk menghadapi krisis ekonomi, politik, dan sosial yang terjadi dalam internal Uni Soviet, para pemimpin Uni Soviet memutuskan melakukan serangan mendadak terhadap Amerika Serikat pada tahun 1989. Amerika akhirnya berhasil bertahan dan melakukan serangan balik, namun masalah muncul kembali kareka China ternyata ikut terjun kedalam peperangan dan bersekutu dengan Uni Soviet. Plot utama game ini secara gamblang menunjukkan agresivitas Uni Soviet dan China serta posisi defensif dari Amerika Serikat yang tidak siap diserang oleh Uni Soviet. Plot yang hampir serupa muncul dalam Operation Flashpoint: Cold War 
Crisis dan Operation Flashpoint: Dragon Rising. Pada judul yang pertama diceritakan bahwa ada seorang jenderal Uni Soviet yang berontak terhadap Gorbachev dan berusaha memulai perang dunia kedua dengan menyerang Amerika Serikat. Pada game ini pemain akan menjadi tentara Amerika dan berusaha mencegah pecahnya perang dengan menghancurkan jenderal pemberontak tersebut. Pada judul yang kedua Amerika Serikat diminta oleh Russia untuk melawan China yang menguasai sebuah pulau milik Rusia. Disini Amerika memiliki musuh baru, China, dan tugas baru, yaitu membantu sekutunya yang diserang oleh sebuah negara aggressor.

Contoh-contoh ini dengan mudah memperlihatkan bahwa ada sebuah mitos yang dikembangkan bahwa Amerika Serikat selalu menjadi negara yang diserang terlebih dahulu dan segala tindakan militer yang mereka lakukan adalah dalam rangka pembelaan diri terhadap serangan aggressor. Mentalitas ini pada kenyataanya memang dapat ditemukan dalam kebijakan Amerika Serikat terutama dalam pemerintahan George W. Bush. Secara eksplisit Bush mengatakan bahwa,

"We cannot defend America and our friends by hoping for the best. We cannot put our faith in the word of tyrants, who solemnly sign nonproliferation treaties, and then systemically break them. If we wait for threats to fully materialize, we will have waited too long - Our security will require transforming the military you will lead - a military that must be ready to strike at a moment's notice in any dark corner of the world. And our security will require all Americans to be forward-looking and resolute, to be ready for preemptive action when necessary to defend our liberty and to defend our lives" (Bush, George W. President Bush Delivers Graduation
Speech at West Point. United States Military Academy West Point, New York. Diunduh dari http://georgewbush-

whitehouse.archives.gov/news/release s/2002/06/print/20020601-3.html.

Pada tanggal 28 Februari 2012 pukul 23:43 WIB).

Kebijakan pertahanan Bush ini secara umum adalah mentalitas dari masyarakat Amerika Serikat yang selalu merasa terancam dan diserang. Pada masa perang dunia ke-2 mereka merasa terancam dengan serangan Nazi, pada masa Perang Dingin mereka terancam oleh serangan Uni Soviet, dan pada masa kini mereka terancam oleh apa yang mereka sebut sebagai kelompok teroris. Selain itu mereka juga masih menumbuhkan perasaan terancam akan komunis China, Korea Utara, Sosialisme Amerika Latin, dan lain-lain. Mitologi penuh ancaman inilah yang kemudian hadir dalam produkproduk game mereka.

\section{Mitos America Always Glory}

Sama halnya yang terjadi dengan tren film perang Vietnam Holywood, Amerika selalu digambarkan menang dan Berjaya dalam berbagai video game. Seri Medal of Honor misalnya, game ini umumnya menceritakan perjalanan seorang prajurit Amerika yang harus melawan ratusan prajurit Jerman atau Jepang dalam perang dunia ke-2 melalui misi-misi infiltrasi. Pada akhirnya sang prajurit berhasil menjalankan semua misinya, seorang diri. Secara umum seluruh seri game ini memang jauh dari akal sehat karena tak pernah dalam sejarah perang dunia ke-2 Amerika Serikat menjalankan misi heroik yang dilakukan hanya oleh satu orang ${ }^{2}$.

2 Amerika pada saat itu memang memiliki organisasi khusus, Office of Strategic Services (OSS) yang digambarkan dalam game ini sering melakukan operasi-operasi khusus, akan tetapi dalam kenyataannya institusi yang sering melakukan operasi khusus selama perang dunia ke-2 adalah pasukan Commando Inggris, dan 
Tema "satu melawan semua" ini tentu tidak hanya hadir dalam serie Medal of Honor, serie Wolfenstein juga menghadirkan cerita heroik yang serupa, bahkan dalam serie ini sang jagoan Amerika digambarkan harus melawan Nazi yang menggunakan ilmu-ilmu paranormal. Selain heroisme melawan Nazi Amerika juga digambarkan secara heroik melawan pasukan komunis Uni Soviet dalam game-game seperti Operation Flashpoint dan Red Alert. Apabila Operation Flashpoint jalan ceritanya bersifat linear, dimana pada akhirnya Amerika pasti menang, maka dalam seri game Red Alert pemain boleh memilih untuk menjadi Amerika atau Uni soviet. Akan tetapi pada akhirnya ini tidak menjadi soal karena secara kanon alur cerita Amerika lah yang akan diambil. Pada seri Red Alert yang kedua Amerika digambarkan telah memenangkan perang dan malahan menempatkan pemimpin boneka di Uni Soviet. Demikian juga pada Red Alert yang ketiga, Amerika digambarkan telah menang sekali lagi melawan Uni Soviet namun kembali harus melawannya lagi (dan juga melawan Jepang). Pada akhirnya Amerika pastilah menang.

Generals juga menghadirkan cerita yang sama dengan alur yang linear. Cerita dimulai dari serangan GLA terhadap China, lalu disusul dengan serangan balik China hingga ke Asia Tengah, disusul lagi dengan serangan balik GLA, dan diakhiri dengan kedatangan Amerika Serikat yang kemudian menyelamatkan China dan menghabisi GLA.

mereka sayangnya tidak pernah mengirimkan satu orang untuk menjalankan sebuah misi, umumnya mereka mengerahkan ratusan pasukan komando dalam menjalankan sebuah misi. Contoh dari operasi khusus ini adalah Dieppe Raid yang tidak hanya dilakukan oleh Commando, namun juga oleh satu unit divisi Canada lengkap.

\section{Mitos The Good Boy}

Pada seluruh video game yang disebutkan Amerika Serikat selalu digambarkan sangat positif sebagai negara yang cinta perdamaian, pacifist, namun juga pemberani, tidak mengenal putus asa, dan penyelamat dunia. Hal yang berkebalikan diberikan oleh lawan-lawan dari Amerika Serikat yang digambarkan kejam, agrresif, terbelakang, bahkan berasosiasi dengan setan. Seri Wolfenstein dengan jelas memperlihatkan bahwa Nazi Jerman tidak hanya berusaha menguasai dunia, namun juga mengaplikasikan ilmuilmu klenik. Disini diceritakan bahwa Heinrich Himmler selaku kepala divisi paranormal Nazi (SS Paranormal Division/Ahnenerbe) berusaha melakukan percobaan-percobaan paranormal seperti membangkitkan orang mati untuk menciptakan prajurit super/ubersoldaten. Disini pemain akan berperan sebagai agen rahasia sekutu yang bertugas untuk menyelidiki dan kemudian menghancurkan eksperimen klenik Nazi tersebut.

Selain Nazi "musuh-musuh" Amerika Serikat lainnya juga sering digambarkan sangat negatif. Selain agresif Uni Soviet dalam Red Alert juga digambarkan kejam. Pada seri game yang pertama misalnya, pemain diperbolehkan membunuh penduduk dengan menggunakan tentara Uni Soviet, sementara pada saat menggunakan tentara sekutu tidak diperbolehkan. Faksi GLA dalam Generals juga digambarkan sangat kejam, pada misi Almaty Supply Raid misalnya, mereka digambarkan merampok konvoy PBB dan bahkan warga mereka sendiri yang telah menerima bantuan PBB. GLA juga digambarkan tega membunuh penduduk mereka sendiri menggunakan senjata kimia Anthrax. Sementara itu Amerika Serikat malah digambarkan datang sebagai pembebas para penduduk tersebut dari penguasaan GLA. 
Sementara itu pada game ini China juga digambarkan sebagai negara yang tidak menghargai HAM dan nyawa manusia. Pada misi A Flood of Violance, mereka digambarkan dengan tangan dingin menghancurkan Three Gorges Dam yang merupakan bendungan terbesar di dunia dan menewaskan banyak sekali penduduk yang tinggal di sekitar sungai. Ketidakperdulian China terhadap nyawa manusia ini kemudian dapat dilihat pada misi berikut, Broken Alliance, dimana mereka digambarkan menganggap enteng racun yang mengalir ke sungai yang banyak digunakan oleh penduduk lokal Tibet. Pesan terakhir ini secara implisit juga menunjukkan dukungan developer game terhadap nasib masyarakat Tibet.

Secara keseluruhan game-game ini juga menggambarkan bahwa Amerika Serikat memiliki persenjataan yang lebih modern, ramah lingkungan, dan manusiawi, sementara itu faksi-faksi lain memiliki persenjataan yang lebih polutif, tidak manusiawi, dan cenderung terbelakang. Pada seri Red Alert misalnya, sekutu/Amerika Serikat digambarkan memiliki teknologi laser/prism serta pengendalian cuaca dan teleportasi. Sementara itu Uni Soviet memiliki teknologi cloning dan nuklir. Pada Generals Amerika Serikat juga digambarkan menguasai teknologi laser, robot, dan penerbangan, sementara itu China bergantung pada jumlah tentara yang besar, produksi tank, dan senjata nuklir. Terakhir GLA digambarkan bergantung pada strategi penyusupan, bom bunuh diri, dan senjata racun.

Nuklir adalah senjata yang memiliki image sangat negatif karena memiliki dampak yang sangat buruk, akan tetapi mengasosiasikan nuklir dengan China adalah kesalahan karena jumlah senjata nuklir China sama sekali tidak sebanding dengan yang dimiliki oleh Amerika Serikat, yaitu 240 berbanding 9400 (Anonim. 7 April 2010. The World's
Nuclear Stockpile. Diunduh dari http://www.aljazeera.com/news/americas/ 2010/04/20104735153263423.html. Pada tanggal 29 Februari 2012. Pukul 00.56 WIB). Demikian halnya dengan senjata kimia yang diasosiasikan dengan fundamentalisme Islam, tentu saja sumber daya yang mereka miliki tidak sebanding dengan lab-lab kimia modern yang dimiliki oleh Amerika Serikat. Seluruh atribut-atribut ini tentunya adalah mitologi yang dibangun untuk membentuk antagonis dari protagonis Amerika Serikat.

\section{PENUTUP}

Fungsi video game bagaimanapun juga adalah hiburan, konsep interaktivitas yang diberikan oleh media ini ditujukan lebih sebagai permainan ketangkasan yang memberikan perasaan senang. Akan tetapi tidak dapat dipungkiri video game juga merupakan media yang memiliki pesanpesan tertentu bagi khalayaknya. Pesan tersebut dapat berupa kekerasan yang hasilnya dapat mengubah psikologis seseorang hingga lebih toleran dalam menerima kekerasan. Pesan tersebut dapat juga berupa informasi-informasi yang mendidik sehingga dapat memberikan pengetahuan yang lebih bagi penggunanya. Pesan ini, terutama, juga dapat berupa pesan-pesan politik yang disadari atau tidak kebanyakan memiliki muatan-muatan yang berat sebelah, diskriminatif, stereotypis, dan stigmatis. Kebanyakan budaya-budaya diluar barat digambarkan terbelakang, kolot, agresif, kejam, dan egois. Sementara budaya barat/Amerika Serikat digambarkan secara luhur, penyelamat dunia, cinta perdamaian, dan selalu menjadi korban.

Level yang dihadirkan oleh para developer game ini tidaklah tanggungtanggung karena hampir seluruh budaya diluar barat ini digambarkan secara negatif sebagai antagonis. Nazi Jerman digambarkan sangat kejam dan menjurus 
pada beraliansi dengan setan. Sementara Uni Soviet digambarkan dekaden, kejam, sangat agresif, dan anti kebebasan. Timur Tengah digambarkan sangat kolot, terbelakang, agresif, kejam, curang, dan tidak berperadaban. China pun digambarkan kejam, agresif, sangat mengancam (karena berpotensi menjadi superpower), dan curang. Bahkan Jepang yang menjadi sekutu Amerika Serikat dan sangat dekat dengan nilai-nilai barat juga digambarkan seperti Jepang era imperial yang sangat agresif, bermental kolot namun berteknologi canggih, senang kekerasan, dan kejam. Kesimpulannya, dimata para developer game, tidak ada budaya diluar barat dan Amerika yang baik. Bisa saja mereka beranggapan bahwa nilai-nilai mereka lebih baik dari nilai-nilai budaya lain, tapi tidak, mereka melihat secara ekstrim bahwa tidak ada budaya yang baik diluar nilai-nilai budaya mereka. Mereka menganggap budaya mereka paling liberal dan demokratis sedangkan budaya diluar mereka sama sekali tidak liberal apalagi demokratis. Mereka juga menganggap bahwa sistem beragama yang sekuler ala merekalah yang terbaik sedangkan budaya diluar mereka dianggap terlalu fundamentalis atau bahkan atheis. Mereka menganggap diri mereka paling pacifist sedangkan budaya lain dianggap agresif. Terakhir mereka memandang teknologi mereka paling maju dan budaya lain lebih kolot dan terbelakang.

Terakhir, developer game ini akhirnya menunjukkan siapakah jagoan sebenarnya, yaitu Amerika Serikat. Mitologi yang dikembangkan disini adalah bahwa Amerika Serikat adalah negara bebas yang paling demokratis dan akan menjaga kebebasan tersebut dengan kekerasan apabila perlu. Game ini juga memelihara mitos bahwa Amerika adalah negara penjaga perdamaian dunia yang berperang hanya untuk keperluan defensif. Padahal mereka-lah salah satu pemilik senjata paling mematikan terbanyak di dunia (nuklir) dan memiliki alokasi dana militer terbesar di dunia. Game ini berhasil membangun mitos bahwa pada akhirnya kebenaranlah yang pasti menang, dan kebenaran itu tak lain adalah demokrasi dan kebebasan yang dilindungi oleh negara terbaik di dunia, Amerika Serikat.

\section{Daftar Pustaka}

Alex Sobur. 2004. Analisis Teks Media: Suatu Pengantar untuk Analisis Wacana, Analisis Semiotik, dan Analisis Framing. Bandung: Remaja Rosdakarya.

Anonymus. 2010. Violence: Shatter the Silence. Listen, Nov; 64. 3: 7.

Barker, Chris. 2005. Cultural Studies. Yogyakarta: Kreasi Wacana.

Culler, Jonathan. 1990. Saussure. London: Fontana Press.

Lee, John K. dan Jeffrey Probert. 2010. Civilization III and Whole-Class Play in High School Social Studies. The Journal of Social Studies Research, Volume 34, Issue 1:1.

Adams, Dan. 2003. Command and Conquer: Generals. Dalam http://pc.ign.com/articles/

385/385453p3.html. Diunduh pada tanggal 23 September 2011 pukul 1:52 WIB.

Anonim.

Dalam http://www.kaskus.us/search_result.ph $\mathrm{p}$ ? $\mathrm{q}=$ Command $+\% 26+$ Conquer $\% 3 \mathrm{~A}$ + Generals\&sa $=$. Diunduh pada tanggal 23 September 2011 pukul 2:27 WIB.

Anonim. Destroying the Native American Culture.

Dalam

http://www.loc.gov/teachers/classroo mmaterials/presentationsandactivities/ presentations/immigration/alt/native_a merican.html. Diakses pada tanggal 29 Februari 2012 pada pukul 16:24 WIB.

Anonim. 2003. Command and Conquer: Generals. Dalam http://www.metacritic.com/ game/pc/command-conquer-generals. 
Diunduh pada tanggal 23 September 2011 pukul 1:51 WIB.

Anonim. 7 April 2010. The World's

Nuclear Stockpile. Diunduh dari http://www.aljazeera.com/news/ameri cas/2010/04/20104735153263423.htm

1. Pada tanggal 29 Februari 2012. Pukul 00.56 WIB.

Becker, David. 2005. Banned in Beijing: China Cracks Down on Games. Dalam http://news.cnet.com/Banned-in-

Beijing-China-cracks-down-ongames/2100-1043_3-5551430.html.

Diunduh pada tanggal 23 September 2011 pukul 2:04 WIB.

Bush, George W. President Bush Delivers Graduation Speech at West Point. United States Military Academy West Point, New York. Diunduh dari http://georgewbushwhitehouse.archives.gov/news/release s/2002/06/print/20020601-3.html.

Pada tanggal 28 Februari 2012 pukul 23:43 WIB.

Calhoun, John C. 1848. Conquest of Mexico. Dalam http://teachingamericanhistory.org/libr ary/index.asp?document=478. Diakses pada tanggal 29 Februari 2012 pada pukul 17:09 WIB.

O'Sullivan, John L. Summer 1845. Annexation. United States Magazine and Democratic Review. Dalam http://www.enotes.com/manifestdestiny-reference/manifest-destiny. Diakses pada tanggal 29 Februari 2012 pukul 16:57 WIB.

Takahashi, Dean. 2003. 2002 Winners. Dalam http://www.gamecriticsawards.com/20 02 winners.html. Diunduh pada tanggal 23 September 2011 pukul 1:55 WIB.

U.S. Grant, Memoirs, On the annexation of Texas and the Mexican War. Diunduh dari http://www.sewanee.edu/faculty/Willi s/Civil_War/documents/Grant.html.
Diakses pada tanggal 29 Februari 2012 pukul 16:37 WIB.

http://georgewbush-

whitehouse.archives.gov/news/release s/2002/06/print/20020601-3.html.

Pada tanggal 28 Februari 2012 pukul 23:43 WIB. 
